\title{
Provision of Inclusive Pedagogy; Support System in Effect among Public Primary Schools in Southern Ethiopia
}

\author{
Meskerem Abera Ayele(M.A) \\ Gender and Inclusive specialist, Research Triangle International (RTI/southern Ethiopia Region)
}

\begin{abstract}
The purpose of this study is to investigate the support system in effect to enhance the effective implementation of inclusive education. The trends of on job teachers' training, provision of peculiar educational inputs needed to implement inclusive education are examined. The study involved a sample of 44 teachers and 11 principals from 11 schools selected from three zones namely Wolaita, Sidama and Hadiya of southern regional state of Ethiopia. Questionnaire, interview, observation and document analysis techniques were used to collect the necessary data. The research target schools were selected as they are labeled as schools of high number of recorded student with special needs in the region. 11 teachers who teach in special unit classes were purposefully selected to be interviewed while 33 teachers who are teaching in the so called inclusive classes were randomly selected to fill questionnaires. School principals, interview participants, were selected by availability sampling. The data collected by these instruments was analyzed both qualitatively and quantitatively. As the research is intended to describe the support system available to implement inclusive education, it is designed to be descriptive survey. Descriptive statistics such as frequency and percentage were used to analyze the data collected from the questioners and document analysis while the data from the interview and observation were analyzed qualitatively. The result of the study showed that teachers who teach in the so called "Inclusive classroom" do not get on job training throughout their teaching career life time while teachers of special unit classes received limited on job training but not enough to make them teach beyond "O" classes. Hence, teachers' and directors' perception towards offering inclusive education found to be distorted. It seems placing students with and without physical disabilities in a single classroom or teaching students with physical disabilities in separated classroom is perceived as the end of offering inclusive education among teachers and school principals. Overwhelming majority of the schools has no school structure responsible to special needs related issues. The schools strategic planning is not inclusive education oriented. The implementation of pedagogy is not supported by assistive technology to address the special learning needs of students with special needs. The overall limited support provided to the school dominantly comes from the neighboring special schools and the modalities of offering special needs education in schools is the replica of these nearby supporting special schools. As a result the kind of special unit classes arranged for students with physical disabilities are limited to special unit classes of deaf and blind students in Hadya and Wolaita zones respectively to replicate the deaf and blind supporting special schools in these zones. In Sidama zone, where there is no any special school special unit classes are not available in the studied schools. Finally, the following recommendations are made. The necessary support system that is important to offer inclusive education need to be primarily established by the government and the society rather than totally shouldered by nearby special schools. The support system need to include offering Successive on job training for teachers, and school principals, establishing school structure responsible to inclusive education related issues, delivery of assistive technology to offer special needs education. The modalities of offering special needs education in special unit classes need to be diversified. Inclusive classes should offer inclusive pedagogy beyond mixing students with and without physical disabilities to accommodate students with diverse learning needs.
\end{abstract}

Keywords: Assistive technology, support system, inclusive education.

\subsection{Background of the study}

\section{INTRODUCTION}

In recent years, the concept and practice of inclusive education have gained international recognition as an educational reform that supports and welcomes diverse educational needs among students (UNESCO, 2009; Nidhi, 2008). Inclusive educational system that is open to all learners regardless of their socio-economic background, learning difficulties, gender, ethnic back ground, seeks to identify and reduce barriers working against inclusive learning of all students. As a basic principle, inclusive education deems all children can learn and achieve well if the learning environment is ready to serve the diverse learning needs of students. It respects different learning needs of students and celebrates diversity as a help than a burden. 
The concern is not only about access to schooling but it is also about ensuring meaningful participation in a system in which achievement and success is available to all. Developing 'School for all' is important because schooling is linked to human, economic and social development goals. Dealing with exclusion, marginalization and underachievement is not only the right thing to do; it makes sound economic and social sense. Failure to develop schools capable of educating all children not only leads to an educational underclass but also social and economic underclass which has serious consequences for society now and in the future. Therefore, the development of successful inclusive school, 'school for all' in which the learning and participation of all children is valued is an essential task for all countries. Positive perception of different learning needs of students is a help as it diminishes exclusion of some strata of a society from education, which is the main get of development (Lewis, 2009; Eleweke and Michael, 2002).

Education is not only one of the basic human right it also plays irreplaceable role in bringing sustainable social and economic development of nations. Elimination of exclusion of citizens from education or realization of inclusive education is indispensable to bring social inequality among citizens (MoE, 2006). UNESCO 2011, states "Inclusive education is essential to achieve social equality and is a constituent element of lifelong learning". In this statement inclusive education is considered as fundamental component of education for all learners which is vital to the development of inclusive society. Inclusive education is also important to elevate self-esteem of citizens that is fundamental to increase the number of productive citizens. This finally boosts both individual and societal prosperity of nations. Realization of inclusive education is highly linked with Education for All and Millennium Development Goals in Education. Both access to and participation in the educational system are the main concerns of MDGs. Inclusion as a strategy is also gaining acceptance to achieve the goals of Education for All (EFA)which is essential element of MDGS. (Bines and Philippa, 2011; MoE, 2012; UNESCO, 2005; UN, 2000).

Ethiopian Government is committed to achieve (MDGs) and (EFA). The country's constitution accepts the international declarations, conventions and states education as human rights. Aligned with the Ethiopian constitution, Educational policy of the country promotes inclusive education. In 1994, the government formulated an education and training policy with an overall goal of providing education for all citizens. Further the government has introduced legal and policy frameworks to realize education for all. Provision of accessible education for persons with disabilities and/or learners with special educational needs is among these wider commitments of the government (MoE, 2004; Ethiopian Education Policy, 1994).In turn the country has shown significant progress in reaching EFA goals. But still the country experienced notable gap in prevailing proper educational system that is inclusive to all Ethiopian children (UNESCO, 2009).

Realizing Inclusive education in its comprehensive meaning is a challenge in both developed and developing countries (Nidih, 2008). The challenge is obviously common in Ethiopia, one of the low income subSaharan countries which experience lack of knowledge about diversity, inadequate preparation of teachers and educational leaders, traditional teaching methods; inflexible curriculum, inappropriate learning equipment, insufficient need identification systems and inadequate assessment procedures are among the specific barriers anticipated in the realization of inclusive education in Ethiopia. These barriers resulted in obliging students with special needs to adapt to the schools instead of adapting schools to the needs of the students (UNESCO, 2009).

\subsection{Statement of the Problem}

In Ethiopia, most often, the issue of bringing inclusive education is considered as enrolment of more and more students with disabilities, arrangement of special unit classes to students with physical disabilities or inclusion of these students in general or mainstreamed class rooms. Ethiopian educational policy directives tend to implement special needs education by accommodating students with special needs under inclusive classroom than special unit classes. Practically however, both modalities go together. Special unit classes are arranged for blind, deaf students; and in rear cases for students with mental development limitations (MoE 2004)

In its comprehensive concept however inclusive education never stops by putting students with special learning needs in a single classroom or mixing students with and without disabilities together in a single classroom rather it goes far long. Creating proper learning environment that is adoptive and responsive of the different developmental capacities, needs, potential of all children is the core principle of inclusive education. This in turn needs jointly established support system among educational leaders, teachers, and other stake holders. It is by this understanding this study had intended to investigate the support system under effect beyond merely establishing special unit classes or mixing of students in mainstream classroom. In so doing, the study attempted to answer the following questions;

1. What support system is implemented to enable inclusive education in the schools?

2. To what extent the inclusive pedagogy being offered in the schools is supported with assistive technology 1.3 Objectives of the study

\subsubsection{General objective}

To investigate the overall support system under way to enhance inclusive pedagogy in public primary schools. 


\subsubsection{Specific objectives}

$>$ To assess the organizational establishment of the schools in addressing students' special learning needs

$>$ To Investigate the efforts made so far to build the capacity of school level actors in offering inclusive education

\section{1}

\section{METHODS AND MATERIALS}

\section{Study Design and Data Analysis Method}

The very objective of this study is to describe the overall support system in effect to enhance inclusive pedagogy in primary schools and the study is designed to be descriptive survey.

The data collected from the questionnaire was quantitatively analyzed using SPSS version 20. Descriptive statistics (frequency count and percentage) were used to describe the available assistive technology to support students with special needs. Information gathered from RSEB documents, interview with special unit class teachers and observation of the learning conditions of students with special needs has been analyzed qualitatively.

\subsection{Population, sample and sampling techniques}

Southern Nations Nationalities and Peoples Region (SNNPR) is one of the nine regional states of Ethiopia. The region totally has 14 zones. 3 out of the entire 14 zones were labeled by the Regional educational bureau as inclusive education intense areas where there were high numbers of registered students with special needs. Accordingly, Sample woredas and cluster schools found in the woredas with relatively high number of registered students with special needs purposefully selected (see table 1). Eleven Sample cluster schools that relatively have numerous numbers of registered students with special learning needs are selected. All teachers who are teaching in special unit classes (13 in number) are selected using availability sampling and interviewed. In addition 4 teachers from each sample cluster school, who teach in regular classes (totally 44) teachers were randomly selected. Principals of the schools (the totally 11) were also interviewed.

Table 1 Sample Zones and respective woredas

\begin{tabular}{|c|c|c|c|}
\hline No & Zone & Woreda & Sample primary and special schools \\
\hline \multirow[t]{4}{*}{1} & \multirow{4}{*}{ 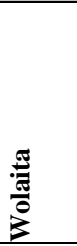 } & Damotwoyide & Bedesa \\
\hline & & Sodo Town & Tigilfire, Otona Blind $\square$ \\
\hline & & SoddoZuria & Gurumowoyide \\
\hline & & Kindokoyisha & Belemedhanialem, \\
\hline \multirow[t]{4}{*}{2} & \multirow{4}{*}{ 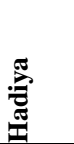 } & Anlymo & Fonko \\
\hline & & Duna & DessaHafle \\
\hline & & MisrakBadewaco & Linda \\
\hline & & Hosaina Town & Haile Bubamo, HosanaSynodos $\square$ \\
\hline \multirow[t]{3}{*}{3} & \multirow{3}{*}{ 芯 } & Arbegona & Kunicha \\
\hline & & Bensa & Genet, \\
\hline & & Aroresa & Mejo, \\
\hline
\end{tabular}

\subsection{Data collection Instruments}

The necessary data was collected using Questionnaire (that holds both open and close ended questions), in-depth interview, document analysis and observation. Questionnaire was used to collect the data from 44 teachers who teach in regular classes. In-depth Interview was conducted to gather information from teachers who were teaching in special unit class. Documents of RSEBs were analyzed to select sample schools that hold large number of students with special needs. Documents in primary schools such as meeting minutes, strategic plans of schools are analyzed to have the information about how frequent special needs education issues are discussed in school senate and to identify the extent to which the issue of special needs education was considered in schools' strategic planning. Observation was conducted to grasp the learning environs of special unit classes; the way they furnished.

\section{RESULTS}

\subsection{Support System in Effect to Enhance Inclusive Pedagogy}

\section{- $\quad$ School Structure Responsible to Special Needs Education Activities}

Regarding the presence of department responsible to coordinate special need education matters in their schools, overwhelming majority of the respondents $(\mathbf{8 1 . 4} \%)$ indicated that there is no any structure in the form of department to coordinate and support special needs education related issues in their schools.(see table 2). This shows that special needs education has not been organized as a department. Hence, the special learning need of students with certain disability or some other special needs is not properly addressed in the schools since there is no prescribed administrative body that is responsible to it. 
Table 2: Response about the availability of special needs department in schools

\begin{tabular}{|l|l|l|}
\hline Response & Frequency & Percentage \\
\hline Yes & $\mathbf{7}$ & $\mathbf{1 8 . 6}$ \\
\hline No & $\mathbf{3 7}$ & $\mathbf{8 1 . 4}$ \\
\hline
\end{tabular}

In the study participants, who responded that their schools have departments of special need education , were asked how many teachers were found in department of special needs holds, as it is shown in chart 1 only one respondent out of the nine participants indicated there were eight members (maximum) in the department. Most of the respondents ( 5 out of 9 respondents) replied that there was only one teacher in the department. It is clear that a department that has one member is not capable of playing significant role in addressing diverse learning needs of students.

Chart 1: Number of teachers in special needs departments of schools

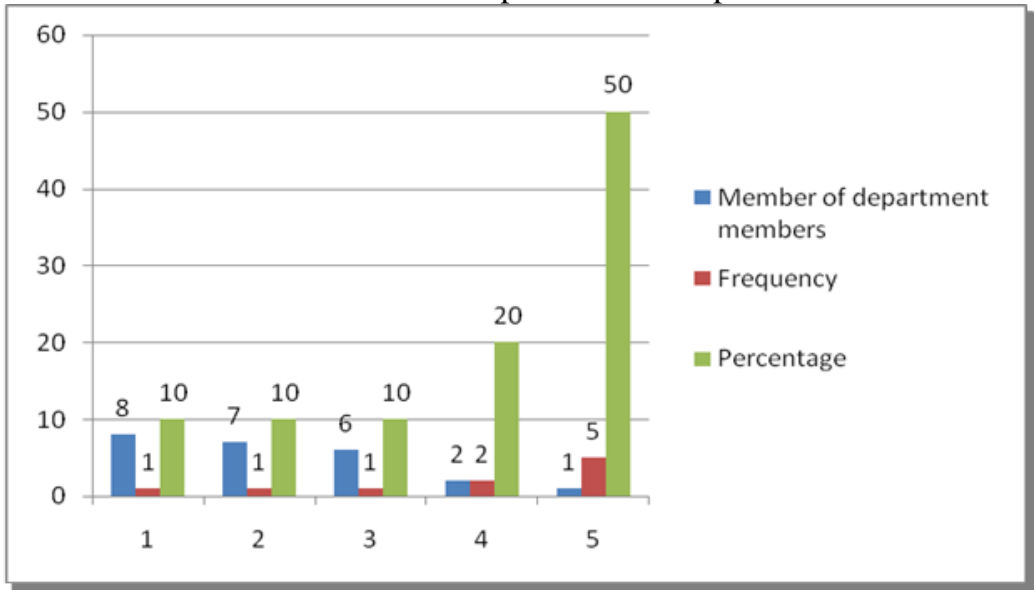

As it is observed in chart 2 below, there are two schools which relatively have large number of members of special needs department. These schools with highest number of department members (8 and 7) were not primary school rather they were special schools of deaf and blind students which are found in Hossana and WoalitaSoddo Towns. As these schools were one of the well-known and long aged special schools even at the national level, they have achieved such better position. The other school with six special needs department teachers is a primary school found in Hossina town, the capital of Hadiya zone. As getting such large number of department members is not common among public schools, the department members were asked how the department can get such large number of members. They replied that since the school located at the urban center, it has an advantage of attracting the scarce number of teachers who are trained in special needs education. The respondents were further asked why teachers trained in special needs education teaching are scarce in number. The respondents explained that the concept of inclusive education is a recently introduced concept in the educational system of Ethiopia and the field of study is not widely given at diploma level which is optimum to primary level. Almost all graduates of special needs education are at Bachelor degree and high levels which is supposed to teach at high school or above level of educational system.

\section{Chart 2: Number of teachers trained in Special needs major field of study}




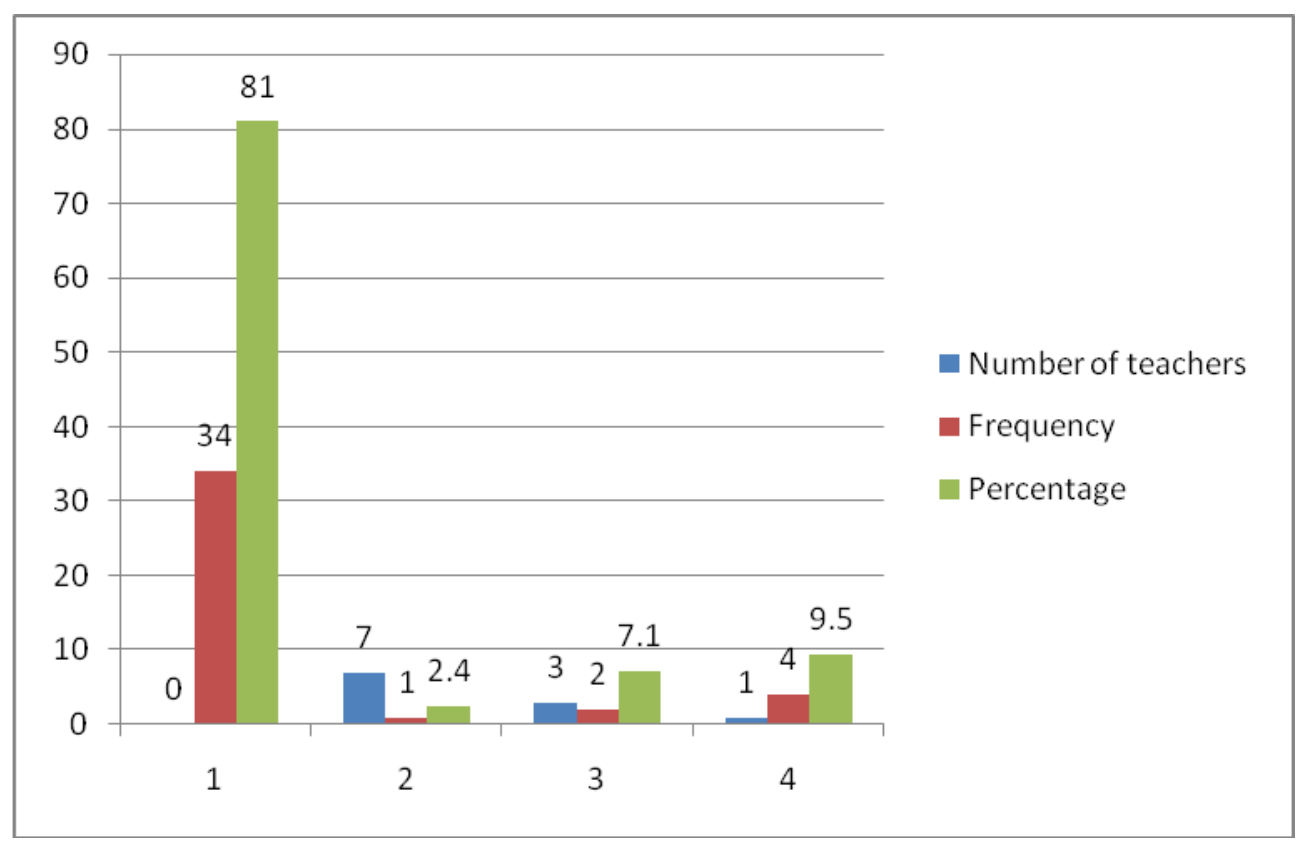

This information of interview respondents is further strengthen by the questioner respondents (teachers of regular class and department heads of special schools) who had been asked that how many of you are trained in special needs as major subject. As their response is summarized on table 4 below, all of the schools found in rural areas have no single teacher who has studied special need education as major field of study. Whereas three public schools found in urban centers or nearby have at least one at most three teacher/s who study special needs as major field of study. The seven teachers shown in table 4 are from Hossaina Sinodos special school of deaf the long aged relatively advanced special school. Next to the HossainaSynodos special school, Ottona special school of blind and Haile Bubamo primary school which found in Hosanna town have relatively high number (3) of teachers who are trained in special needs as major subject.

- Capacitating teachers with basic skills of offering special needs pedagogy

Table 3: Number of teachers who took on job training in special needs

\begin{tabular}{|l|l|l|}
\hline $\begin{array}{l}\text { Number of teachers } \\
\text { trained }\end{array}$ & $\begin{array}{l}\text { Frequency of training } \\
\text { session }\end{array}$ & Percentage \\
\hline 27 & 0 & 61.3 \\
\hline 10 & 1 & 22.7 \\
\hline 6 & 2 & 13.6 \\
\hline 1 & 4 & 2.2 \\
\hline
\end{tabular}

Teachers were also asked whether they have had opportunities to get on job training. As the summarized response indicates (See table 3) majority of the respondents $(61.3 \%$ ) have signified that there were no on job trainings offered to capacitate teachers with the necessary skills and knowledge in offering special need sensitive pedagogy. One teacher replied that he had got on job training four times in Hosanna "synodos" special school of deaf. Six teachers of Haile bubamo and four teachers in Fonko primary schools responded as they took on job training for four and two times respectively. Haile Bubamo School is found in Hosanna town while Fonko primary school is located in the vicinity of Hosanna town. This implies that special schools and public primary schools which are found in or around urban centers have more opportunities to get on job trainings.

So as to substantiate the information gained from the questioner, interview was conducted with teachers who took the on job training. According to the interview respondents, the on job training were offered were initiated by the nearby special schools, that is, Hossana special school of deaf in case of Hadiya zone respondents and Ottona special school of blind in the case of Woilaita zone. In case of Sidama zone here there was no any special unit school, no on job training was offered. From this it is possible to conclude that it is the special schools of deaf and Blind in Hossana and Wolaitasoddo which were playing the great role in enhancing special needs education.

The strong influence of these two special schools is reflected by the type of special unit classes established in studied primary schools. In the case of Hadiya zone, all except one of the special unit classes observed are special unit class of deaf students. The only exception in Hadya zone was the special unit class 
which holds students with mental development limitations. In case of wolaita the type of special unit classes are dominantly special unit classes of students with visual impairment. According to the interview respondents most supports for special needs education came from Ottona special school of blind and Hossana special school of deaf.

Interviewed teacher explained that even though the trainings they had received from two special schools (Hosana special school of deaf students and Wolaita special school of blind students) were significantly helped them in teaching students with special needs in special unit classes; it was difficult to say they were well trained to satisfy the special learning needs of their students. Respondent teachers underlined that the training they took was enough only for "O" class and they find teaching difficult as the grade level increases.

The respondents highlighted that the maximum training session they attend was 45 days while the minimum training session was 15 days. It was using the skill they gained on these trainings that the teachers were teaching from "O" class and grade 3 special unit classes. Even worse, the number of teacher trained for such short duration of time was one in each school as the researcher observed. As a result of scarce trained teachers, there are no grade 1 and 2 special unit classes in the targeted schools. The only existing class is grade 3 and "O" class. As the data grasped from the observation and interview demonstrated there was only one teacher in each primary school who was supposed to teach all grades of the special unit classes. This situation creates burden on teaching load covered by a single teacher and due to this certain classes of special need students were left without special need teacher. As the interview respondents clarified, the tied teaching condition they were in, they were obliged to leave one of the two classes free to teach the other one, that is, grade 3 students will be free to teach "O" class and vice versa.

\subsection{Availability of Assistive technology to support special needs pedagogy}

Concerning whether there are initiatives to support the proper implementation of special needs education, $40.5 \%$ of the respondents assured that their school had never received any support from outside body other than school internal revenue so far. Thus, they use their school internal revenue which was very low to procurement of equipments needed to conduct special needs education. $11.9 \%$ of the respondents explained that their schools received certain support from NGOs and $2.4 \%$ of their counterparts said that there were some support from government and NGOs jointly. Government alone provided support was indicated in $21 \%$ of the respondents.

Regarding the type of learning materials supports delivered so far it is summarized in table 4 below. Most of the respondents (47.6\%) replied that stake holders conducted need assessment and promised to provide some support but not yet received. The frequent kind of support comes in the form of financial grant, especially from NGOS, to buy school uniforms, stationeries, audiovisual devices, playing equipments. Provision of teaching learning materials such as exercise book, sign language dictionary/video, TV, etc are also significant ways of supporting learners with special learning needs.

Table 4: Forms of material support

\begin{tabular}{|l|l|l|}
\hline Form of support given & Respondents \\
\cline { 2 - 3 } & Frequency & Percentage \\
\hline Financial Grant & 11 & $\mathbf{2 6 . 2}$ \\
\hline Refreshments for students with special needs & & 2.4 \\
\hline $\begin{array}{l}\text { Teaching learning equipment (Uniform, exercise } \\
\text { book, teaching aids, sign language dictionary/video, } \\
\text { hearing aid, slate and stylus ,TV, Table tennis } \\
\text { equipment, mat, flash cards ) }\end{array}$ & $\mathbf{2 3 . 8}$ \\
\hline $\begin{array}{l}\text { Need assessment and promise to support according to } \\
\text { the need from Government }\end{array}$ & $\mathbf{2 0}$ & \\
\hline
\end{tabular}

The studied schools have no any assistive technology to help students with disabilities. Hence, students with hard of hearing and low vision are considered as normal. In most cases the interviewed school principals did not have the idea about the possible special learning needs students with low vision and hard of hearing that appear since they except only students who are totally deaf and blind are students with special learning needs.

\section{DISCUSSION AND CONCLUSION}

\subsection{Teachers' Capacity Building and organizational Support System}

Successful implementation of inclusive education needs wider range of support system extended from policy directives to school system. Support system at school level starts with academic organizational structure that vouches inclusive education issues. The findings of this study however signified dominant majority of the schools $(81.4 \%)$ did not have responsible department to coordinate and manage special needs related issues. The data gained from document analysis of the school minutes and strategic plan documents shows that inclusive education related issues were less discussed in schools' senates and less considered in schools' planning. This in 
turn hampered the tendency of considering special needs issue in overall strategic planning of the schools including budgeting, teachers on job training, and educational input provision for students with special needs. This go together with the findings of Lwise, 2009 that describe inclusive classes found in developing countries like in Ethiopia are characterized by low quality and lack of regulation.

Comparatively special schools established in urban centers and primary schools that are located nearby urban centers had better school academic structures responsible for special needs education. In other words, primary schools which are placed far away from urban centers had low tendency of accommodating inclusive education issues in their pedagogy. Ethiopia's placement among the least urbanized states of the world makes the condition worse. This finding is similar to Lewis, 2009 findings that concluded inclusive schools/special unit classes in Ethiopia are often poorly staffed, under resourced and dominantly concentrated in urban areas.

The concept of inclusive education is a recent phenomenon in Ethiopian educational system. The numbers of higher education who were training special needs education professionals were limited. The scarce number of teachers trained in special needs education takes the advantage of working in schools found in urban areas. This resulted in concentration of special need education teachers at school located in urban areas while schools in rural areas did not had single special needs professional teachers. From this it is possible to understand that schools that are located in urban centers are positioned more advantageous to offer special needs sensitive pedagogy than those schools found in rural areas.

As large numbers of primary schools in Ethiopia are found in rural areas, total absence of trained special needs teachers in rural areas and relative concentration in urban centers obviously had an adverse effect on proper implementation of wide scale special needs sensitive pedagogy. To substantiate this phenomena, (Susie Miles, 2000) indicated that distance, and apparent isolation from the centre, or from the nearest town, are two of the main barriers commonly identified in rural areas. Consequently, it was very difficult to recruit wellqualified special need teachers for posts in remote areas in all countries. Teacher education and ongoing support and training are therefore crucial to the proper implementation of inclusive education.

In such huge absence or scarcity of teachers trained in special needs education fields of study, on job training can be the alternative way of capacitating the teachers with basic skills of managing diverse learning needs of students. The finding of this study however did not show teachers were receiving satisfactory on job training trends to complete their capacity gaps in addressing the diverse learning needs of such students. Majority of the teachers (61\%) had never received special need education related on job training. $22 \%$ of teachers replied as they have received one on job training which ranged from 15 days to 45 days and they further explained as it was not enough to teach upper grades beyond "O" classes. Even worse, it was the teacher who had attended the referred short term training in each school who was supposed to teach in all special unit classes in their prescribed schools. The schools under study had grade 1-3 special unit classes. This put teachers in a double aged difficulty in the course of addressing the special learning needs of their students. Primarily, they rose about the less self- efficacy they had about their own capacity to offer special needs education with such shortest term training. Secondly, they complain about their super-busyness to teach all the special unit classes in their schools alone and this sometimes resulted in leaving some of students to go home in schooling periods to teach other classes. This in turn will hinder them from completing the lessons on time. From the other corner, interviewed Schools principals explained that special unit class students who left free during class period due to scarcity of teachers often disturb other students who are learning in nearby classes.

The scarce on job teachers trained in the schools were totally initiated and offered by the special schools found in the studied zones. As the primary schools were dominantly supported by the nearby special schools, they have strong influence in the special needs related pedagogy of the studied schools. To mention, the special unit classes established in the studied schools are the replica of the supporting special schools. The special school found in wolaita zone were special school of deaf students and the special unit classes observed in all worada of the studied primary schools were dominantly special unit classes of deaf. In the same token, the special classes observed in primary schools of all wordas in Hadiya zone were special unit classes of blind students, which was the replica of the Hosana synodos special school of blind. In the case of all woreda observed in Sidama Zone no special unit class had been observed since there was no influential and long aged special school to influence the schools.

\subsection{Assistive Technology Related Support System in Effect}

According to Susie Miles (2000), resource barriers are the most widely used excuses for not promoting inclusive practice. In the advanced world, teachers often claim that they would be capable of so much more, 'if only there were more resources'. Lack of resources is perceived as a barrier to inclusion across cultural, geographical and economic boundaries. Educational resources for students with learning needs are more expensive to seek huge amount of budget as they are technology oriented and imported in the case of under developed world. Ethiopia as one of the low income countries of sub-Saharan Africa is no exception to this; even the economic under development of the country worsen the problem. 
The realities observed in schools under investigation and the data gained from interview with principals, teachers and document analysis of schools' property recordings show that the available resources are by far lesser than the potential need of students with special learning needs. Schools use the limited internal revenue budget to buy educational inputs necessary for special needs education such as sign language dictionary and brail papers to offer special needs education. The budget support given by educational bureau was very limited across the studied schools. In most cases, Educational bureaus did not do beyond conducting need assessment. Limited support comes from NGOS and religious charity organizations was in the form of electronic and non-electronic equipments such as TV, Table, chair, Pictures, posters, Radio, carpet, sign language teaching video, sign language dictionary, stylus and slate.

Learning environment paired with assistive technological devises provide meaningful and least restrictive learning condition which gives rise to meaningful educational benefit for students with special educational needs. In the studied schools context, however, the above mentioned electronic and non-electronic equipments referred by the research participants as assistive technology devises are not enough to support the diverse educational needs of students with special learning needs in a meaning full manner. Primarily, the studied schools did not updated assistive technological devises which go parallel with the 21 century. Most technological devises referred by the respondents were TV and tape recorders which less updated technologies of this time technological standard and less helping to students with visual and hearing impairment, which is the most frequent type of physical disability, observed in the studied schools. Moreover, the schools under investigation have no assistive technology in effect to identify the level of disability of students. Hence, students who are partially impaired are considered as "normal" and do not receive any special need oriented pedagogy.

\section{RECOMMENDATIONS AND LIMITATIONS OF THE STUDY}

Findings of the study showed that primary schools have no schools structure which is responsible to vouch proper implementation of special needs education. However the existence of school structure responsible to special needs education is among the crucial support system to enhance special needs education. Hence, schools need to have such structures to have special needs sensitive pedagogy.

It is well known that teachers have irreplaceable role in realizing special need sensitive pedagogy. School principals also have crucial role in school planning, establishing support system in schools are also important role to play in enhancing inclusive education sensitive support system. To this end, teachers' and schools principals'capacity needs to be built through successive on job trainings and the regional, Zonal, and woreda educational bureaus need to take the lead in arranging such successive trainings.

The findings of this study shows the special needs education pedagogy being offered is not supported by assistive technology to address the special needs of students with certain disabilities. Hence, the special needs education pedagogy need to be supported by assistive technological devices. As procurement of assistive technologies is difficult be hold by educational bureaus or schools parents, charity organizations, NGOS need to join their hands to identify, procure and deliver assistive technologies.

This study was conducted on three zones of one regional state of Ethiopia called southern Nations Nationalities and Peoples Region namely Hadiya, Sidama and Wolaita zones. Further study using a larger sample of schools from different regions of the country would be recommended so as to have clearer picture of the issue under study.

The study is limited to the support system in effect to in school domain only. However, effective implementation of inclusive education needs wider support system our side of the schools too. Inclusive education has cultural, psychological and economic dimensions and effective implementation of inclusive education need to have wider perspective study to considering all these. Hence, the support system rendered from families, advocacy groups, civic organizations need to be investigated.

The results of this study showed that teachers received little or no job trainings about instruction of diverse needs of students. Hence teachers have faced problems related to addressing diverse needs of students placed in the so called inclusive schools. But the study has not extended to investigate to what extent the preservice trainings have helped teachers in offering inclusive education. Thus, it is recommended to study the role of pre-service training in helping teachers' implementation of inclusive education.

\section{REFERENCES}

[1]. Bines, Hazel, and Philippa Lei (2011) 'Disability and education: The longest road to inclusion',International Journal of Educational Development, vol. 31, no. 5, pp. 419-424.

[2]. Eleweke, C. Jonah, and Michael Rodda (2002) 'The challenge of enhancing inclusive education in developing countries', International Journal of Inclusive Education, vol. 6, no. 2, pp. 113-126.

[3]. Florian, L. and Rouse, M. (2009) The inclusive practice project in Scotland: Teachereducation for inclusive education. Teaching and Teacher Education, 25 (4), 594-601

[4]. International Labor Organization (ILO) (2013), Inclusion of People with Disabilities in Ethiopia,[Electronic], Available: http://www.ilo.org/wcmsp5/groups/public/@ed_emp/@ifp_skills/documents/publication/wcms_112299.pdf [17 Oct 2013] 
[5]. Lewis, Ingrid (2009) Education for disabled people in Ethiopia and Rwanda, [Electronic],Available: http://unesdoc.unesco.org/images/0018/001865/186564e. pdf [21 June 2015]. Ministry of Education (MoE),(1994) Ethiopian New Educational and Training Policy, Addis Ababa.

[6]. Ministry of Education (MoE) (2006) Special Needs Education Program Strategy: Emphasizing Inclusive Education to Meet the UPEC and EFA Goals, Addis Ababa.

[7]. Ministry of Education (MoE) and UNICEF (2012) Study on situation of out of school children (OOSC) in Ethiopia, [Electronic], Available:http://www.unicef.org/ethiopia/OSCStudyReport2012.pdf [25 Oct 2013].Ministry of Education (MOE) (2012) Special Needs/Inclusive Education Strategy, Addis Ababa.

[8]. Singal, Nidhi (2008) 'Working towards inclusion: Reflections from the classroom', Teaching and Teacher Education vol. 24, no. 6 , pp.1516-29.

[9]. Susie, Miles. Workshop paper presented at: A Symposium on Development Policy entitled, "Children with Disabilities and the Convention on the Rights of the Child", Gustav Stresemann Institute, Bonn, Germany, October 27-29, 2000

[10]. UNESCO (2000) Inclusive Education and Education For All: A challenge and a vision.

[11]. UNESCO (2005) Children out of school: Measuring exclusion from primary education. Montreal: UNESCO Institute for Statistics.

[12]. UNESCO (2009) Policy Guide Lines on Inclusion in Education. Paris, UNESCO.

[13]. UNESCO International Bureau of Education, 2009. International Conference on Education. Inclusive Education: The Way of the Future 28International Literature Review 64 th Session Geneva 25-28 November 2008. 